\title{
Accountantshonoraria in de
} jaarrekening

Wilfred Kevelam, Ralph ter Hoeven en Tristan Brouwer

SAMENVATTING In deze bijdrage presenteren we de resultaten van een empirisch onderzoek naar de kwaliteit van de toelichting op accountantshonoraria in de jaarverslaggeving over 2016. Uit het onderzoek blijkt dat de toelichting op accountshonoraria over het algemeen vrij beknopt is. Veel ondernemingen presenteren wel de meest noodzakelijke cijfermatige informatie, zijnde de uitsplitsing van de accountantshonoraria. Een nadere toelichting op de gehanteerde methode van toerekenen van accountantshonoraria of de ontwikkeling in de hoogte en samenstelling van accountantshonoraria ontbreekt echter veelal. Gezien de maatschappelijke aandacht voor accountantshonoraria is verbetering in de toelichting volgens ons zeker mogelijk en wenselijk. Tevens is de ontwikkeling in de hoogte en samenstelling van accountantshonoraria over de periode 2012 tot en met 2016 geanalyseerd. We constateren dat het aandeel van honoraria voor controlewerkzaamheden in de totale accountantshonoraria sterk is gestegen ten opzichte van honoraria voor overige niet-controlewerkzaamheden. Dit verhoogt de gepercipieerde onafhankelijkheid van de accountant. Ons onderzoek toont voorts aan dat de gevolgen van accountantskantoorroulaties voor de hoogte van accountantshonoraria niet eenduidig zijn. Bij AEX-ondernemingen zien we dat een wisseling van accountant leidt tot een aanzienlijke daling van het accountantshonorarium, terwijl dit effect niet zichtbaar is bij AMX- en AScX-ondernemingen. Dit diffuse beeld is consistent met bestaande literatuur.

\section{RELEVANTIE VOOR DE PRAKTIJK Relevante en duidelijke informatie over accoun-} tantshonoraria is van belang voor gebruikers van de jaarrekening om de onafhankelijkheid van de externe accountant te evalueren. In deze bijdrage gaan we in op de kwaliteit van de toelichting op accountantshonoraria en illustreren we deze kwaliteit met een aantal best practices. 0ok beschrijven we de ontwikkeling in de hoogte van accountantshonoraria naar aanleiding van de verplichte accountantskantoorroulaties die in de periode 2013 tot en met 2016 hebben plaatsgevonden. Voor opstellers, controleurs en gebruikers van jaarrekeningen biedt deze bijdrage daarmee de nodige context om de kwaliteit van de toelichting op accountantshonoraria te analyseren, te verbeteren en trendmatigheden te ontdekken.

\section{INLEIDING}

In de academische literatuur is veel onderzoek gedaan naar accountantshonoraria. Hieraan liggen twee belangrijke onderzoeksdoelstellingen ten grondslag. Het eerste doel is om de mate van concurrentie binnen de accountancysector te evalueren, mede in het licht van het beperkte aantal (internationale) aanbieders van accountantsdiensten. Zo hebben Boonzaaijer, Van der Lecq en Van Veldhuizen (2014) in een Nederlandse context de concurrentie-effecten van de verplichte accountantskantoorroulatie verkend en de implicaties daarvan voor de prijs en kwaliteit van controlediensten binnen de financiële sector onderzocht. Het tweede doel van onderzoek naar accountantshonoraria is om deze te relateren aan de onafhankelijkheid van de externe accountant. De hoogte van de vergoeding die de accountant ontvangt voor de controle van de jaarrekening en de verhouding tussen deze vergoeding en de vergoedingen voor overige niet-controlediensten geven immers inzicht in de gepercipieerde onafhankelijkheid van de accountant (DeFond, Raghunandan \& Subramanyam, 2002) Als de accountant overige niet-controlediensten levert aan zijn cliënt in aanvulling op de controle van de jaarrekening, ontstaat er een hogere mate van economische verbondenheid tussen accountant en cliënt, hetgeen een bedreiging kan zijn voor de onafhankelijkheid van de accountant.

De implementatie van de verplichte accountantskantoorroulatie in de Europese Unie (EU) geeft wetenschappelijk onderzoek naar accountantshonoraria een nieuwe impuls. De verplichte accountantskantoorroulatie volgt uit de Europese Verordening (537/2014) die in april 2014 door het Europees Parlement en de Europese Raad is aangenomen. De Verordening is op 17 juni 2016 rechtsreeks in werking getreden in de Europese lidstaten en richt zich op de verbetering van de accountantscontrole bij organisaties van openbaar belang (OOB's). In dit kader introduceert de Verordening onder meer een verplichte accountantskantoorroulatie na maximaal tien aaneengesloten jaren. Hierbij geldt een overgangsregime tot uiterlijk 17 juni 2024. Vervolgens dient een afkoelingsperiode van minimaal vier jaar in acht te worden genomen. Voor de roulatie van de (persoonlijke) externe accountant geldt een maximaal aaneengesloten periode van vijf jaar. ${ }^{1}$

Nederland liep overigens met het amendement-Van Vliet op de Wet op het accountantsberoep (Wab) al voor op de verplichte accountantskantoorroulatie. Dit wetsvoorstel werd eind 2012 in de Eerste Kamer aangenomen en verplichtte Nederlandse OOB's om voor 
1 januari 2016 te wisselen van accountantskantoor. De door dit amendement aangepaste Wet toezicht accountantsorganisaties (Wta) schreef een maximale roulatietermijn van acht jaar voor. Uiteindelijk zijn deze $\mathrm{Ne}$ derlandse regels aangepast aan de in 2014 gepubliceerde Europese Verordening (537/2014), zoals hierboven geschetst. Het gevolg is echter wel dat een groot aantal Nederlandse OOB's al eerder van accountantskantoor gewisseld is dan strikt noodzakelijk onder de Europese Verordening. Deze roulaties hebben grotendeels in de boekjaren 2014 tot en met 2016 plaatsgevonden. Het boekjaar 2016 is derhalve het laatste jaar van een kortstondige periode waarin nagenoeg alle Nederlandse beursgenoteerde ondernemingen zijn gewisseld van accountant. Dit maakt dat de maatschappelijke aandacht voor de ontwikkeling van accountantshonoraria hoog is. De toelichting op deze accountantshonoraria in de jaarverslaggeving over 2016 is dan ook het object van ons onderzoek. Naast de kwaliteit van de toelichting op accountantshonoraria analyseren we ook de ontwikkeling in de hoogte en samenstelling van deze accountantshonoraria over de periode 2012 tot en met 2016. De centrale onderzoeksvraag hierbij is: wat is de kwaliteit van de toelichting ten aanzien van accountantshonoraria in de jaarverslaggeving over 2016 en welke ontwikkeling is waar te nemen in de hoogte en samenstelling van deze accountantshonoraria ten opzichte van voorgaande jaren?

Het vervolg van dit artikel is als volgt opgebouwd: in paragraaf 2 beschrijven we bestaande regelgeving omtrent de toelichting op accountantshonoraria. Hierbij schetsen we enkele achtergronden bij de wetsgeschiedenis en benoemen we onduidelijkheden ten aanzien van de huidige wettekst. Paragraaf 3 omvat het empirisch onderzoek. Allereerst beschrijven we de opzet van het onderzoek en de onderzoekspopulatie. Vervolgens presenteren we de resultaten van het empirisch onderzoek. We sluiten deze bijdrage af met enkele conclusies en een nabeschouwing.

\section{Wet- en regelgeving met betrekking tot accountantshonoraria}

Wetgeving omtrent de toelichting van accountantshonoraria vindt haar oorsprong in de implementatie van de door de Europese Raad en het Europees Parlement uitgebrachte Richtlijn 2006/43/EG (hierna: 'de Richtlijn') betreffende de wettelijke controles van jaarrekeningen en geconsolideerde jaarrekeningen. De Richtlijn vervangt de Achtste EEG-Richtlijn inzake de toelating van personen, belast met de wettelijke controle van jaarrekeningen en beoogt een veelheid van zaken rond de wettelijke controle van jaarrekeningen binnen de EU te harmoniseren. Zo worden er ten opzichte van de voorgaande Richtlijn verdergaande eisen gesteld aan de individuele accountant (in termen van onafhankelijkheid en deskundigheid) en de accountantsorganisatie belast met de wettelijke controle van jaarrekeningen. Veel zaken die in de Richtlijn worden geregeld stemden al overeen met toenmalige Nederlandse wetgeving (vooral opgenomen in de Wet toezicht accountantsorganisaties, Wta). Maar een aantal zaken behoefde nog wel implementatie in de Nederlandse wet. Eén daarvan handelde over de transparantie van honoraria van accountants, vermeld in artikel 49 van de Richtlijn. Dit artikel, amendeerde de Vierde en Zevende EEG-Richtlijn ${ }^{2}$ handelend over de (geconsolideerde) jaarrekening. De transparantie van accountantshonoraria wordt hiermee afgedwongen door een verplichte toelichting in zowel de vennootschappelijke als de geconsolideerde jaarrekening. De reden om hierover transparant te zijn wordt nadrukkelijk aangegeven in de Richtlijn zelf. Zo vermeldt de inleidende paragraaf 11 dat een bedreiging van de onafhankelijkheid van de accountant of zijn organisatie gelegen kan zijn in het verrichten van bijkomende nietcontrolediensten en de hoogte van het ontvangen honorarium.

De verankering van de Europese Richtlijn in de Nederlandse wet heeft geleid tot toevoeging van artikel 382a in Titel 9 in Boek 2 BW (zie bijlage 1 voor de volledige tekst) dat op 28 juni 2008 in werking trad. Dat betekent dat in ieder geval vanaf boekjaar 2008 de vereiste toelichting over accountantshonoraria in de jaarrekening zou moeten zijn opgenomen.

Vanaf het moment van inwerkingtreding heeft dit wetsartikel tot vragen geleid (Dieleman, 2008; Langendijk \& Speijcken, 2010; Langendijk, 2011). Een van deze vragen werd door de Minister tijdens de wetsgeschiedenis al geadresseerd en handelde over de vraag welke honoraria feitelijk nu bedoeld zijn. Zijn deze nu gerelateerd aan werkzaamheden die door de accountants tijdens het boekjaar zijn verricht of dienen de kosten samenhangende met de controleopdracht van een boekjaar (ongeacht of de werkzaamheden gedurende het boekjaar zijn verricht) te worden toegelicht? De Minister merkt deze onduidelijkheid wel op ${ }^{3}$, maar heeft verzuimd deze door een duidelijke wettekst (of toelichting daarop) weg te nemen. De RJ heeft over de kwestie een separate Uiting uitgebracht (2013-16) omdat volgens de RJ bleek dat in de praktijk beide methodes werden toegepast. Na ontvangst van het bij de RJ ingediende commentaar bleek dat de laatstgenoemde methode (honoraria koppelen aan de controleopdracht ongeacht wanneer werkzaamheden hebben plaatsgevonden) een sterke voorkeur geniet. ${ }^{4}$ Vandaar dat de RJ de aanbeveling doet deze methode te hanteren. Daarnaast is aan RJ 390 een stellige uitspraak toegevoegd dat de rechtspersoon de gebruikte methode dient toe te lichten. De stellige uitspraak en aanbeveling hadden een ontwerp-status voor boekjaar 2015 en zijn ingegaan voor boekjaren aanvangend op of na 1 
januari 2016. Uiteraard vormt dit aspect onderdeel van ons empirisch onderzoek.

Naast de toerekeningsvraag van het accountantshonorarium aan boekjaren, riep de wettekst een andere meer fundamentele onduidelijkheid op en wel die van de reikwijdte van de accountantsorganisatie zelf. De wettekst spreekt over de externe accountant en de accountantsorganisatie zoals genoemd in artikel $1 \mathrm{Wta}$. Het gaat hier dus om vergunninghoudende accountantsorganisaties die onder toezicht van de AFM vallen, zoals Deloitte Accountants B.V. Er is dus geen verplichting om de honoraria van het netwerk (Deloitte) van de accountantsorganisatie te vermelden. Ook is er geen verplichting om honoraria te vermelden voor diensten die zijn uitgevoerd door buitenlandse accountants van hetzelfde netwerk. Deze buitenlandse accountants vallen namelijk ook niet onder de definities van artikel 1 Wta. Er is verder geen verplichting om de honoraria van ondergeschikte accountantsnetwerken te vermelden. ${ }^{5}$

In het licht van de doelstelling van de wetgever, namelijk oordeelsvorming over de onafhankelijkheid van de accountant, is het opmerkelijk dat naar de letterlijke weergave van de wettekst er geen informatie hoeft te worden gegeven over de hierboven genoemde honoraria. Het bezwaar van te beperkte informatie over accountantshonoraria werd al snel onderkend en bracht het toenmalige NIVRA in februari 2009 tot publicatie van een niet-bindende NIVRA-Wijzer waarin de volgende aanbevolen wijze van vermelding van accountantshonoraria in de jaarrekening wordt gegeven:

De RJ heeft reeds in maart 2009 een brief aan de Minister gestuurd om erop aan te dringen de aanbeveling van het NIVRA door middel van een wetsaanpassing te honoreren. In tegenstelling tot de kleine reparaties van de hiervoor genoemde onduidelijkheden heeft de wetgever hieraan tot nu toe geen gehoor gegeven om voor ons niet te achterhalen redenen. We vermoeden dat de wetgever meent dat met een dergelijke aanpassing te veel wordt afgeweken van artikel 49 van de Richtlijn, maar dan zouden toch alleszins initiatieven kunnen worden ondernomen om dit artikel zelf aan te passen. Daar is tot op heden geen sprake van.
Overigens merken we op dat de term 'andere niet-controlediensten' in de genoemde tabel wel erg generiek is geformuleerd. In het kader van het oordeel van de onafhankelijkheid van de accountant is het uiteraard ook van belang dat inzicht wordt verkregen in de aard van deze overige werkzaamheden. Zo hebben de toenmalige organisaties NIVRA en NOvAA al in $2002^{6}$ een soortgelijke indeling als nu in artikel 382a is opgenomen voorgesteld, met dien verstande dat ook werd aangegeven de categorie andere niet-controlediensten als volgt te specificeren:
a. financiële informatietechnologie;
b. interne controle;
c. waardebepaling;
d. rechtsbijstand; en
e. werving van personeel.

Naar onze mening is het een gemiste kans dat deze onderverdeling niet in de Richtlijn en/of wettekst is opgenomen. Wel dient beseft te worden dat op grond van artikel 24b Wta een accountantsorganisatie die wettelijke controles verricht bij een OOB naast deze controlediensten geen andere werkzaamheden voor die organisatie en aan die organisatie gelieerde entiteiten mag verrichten. Artikel 24b Wta is overigens ingegaan per 1 januari 2013. ${ }^{7}$ Gezien het feit dat de door ons onderzochte beursorganisaties per definitie OOB's zijn, mag verwacht worden dat vanaf 2013 naast de wettelijke controle van de jaarrekening en mogelijk andere controleopdrachten relatief weinig honoraria voor andere vormen van dienstverlening worden vermeld. Desalniettemin blijft de verhouding tussen honoraria voor de controle van de jaarrekening versus andere (controle)opdrachten een interessant onderzoeksgebied vanwege de eerder genoemde bedreiging van de gepercipieerde onafhankelijkheid van de controlerende accountant.

\section{EMPIRISCH ONDERZOEK}

\subsection{Onderzoeksopzet en -populatie}

De onderzoekspopulatie bestaat uit ondernemingen die ultimo 2016 zijn opgenomen in de Nederlandse AEX-, AMX- en AScX-indices. De totale onderzoekspopulatie bestaat derhalve uit 75 beursgenoteerde on-

Tabel 1 Aanbevolen wijze van vermelding van accountantshonoraria (bron: NIVRA-Wijzer 1)

\begin{tabular}{|l|l|l|l|}
\hline & X Accountants & Overig X netwerk & Totaal X netwerk \\
\hline Onderzoek van de jaarrekening & & & \\
\hline Andere controleopdrachten & & & \\
\hline Adviesdiensten op fiscaal terrein & & & \\
\hline Andere niet-controlediensten & & & \\
\hline Totaal & & & \\
\hline
\end{tabular}


dernemingen. Tabel 2 geeft een aantal belangrijke kenmerken van de onderzoekspopulatie weer; voor een volledig overzicht van de onderzochte ondernemingen verwijzen we naar bijlage 2 . Voor deze ondernemingen hebben wij de toelichting op de accountantshonoraria in de jaarrekening 2016 geanalyseerd en beoordeeld. Voor ondernemingen met een gebroken boekjaar is de jaarrekening aangemerkt in het jaar van de publicatie. Dit houdt in dat een jaarrekening over het boekjaar $2015 / 2016$ is meegenomen als een jaarrekening over 2016.

Tevens hebben wij de hoogte en ontwikkeling in accountantshonoraria inzichtelijk gemaakt voor de periode 2012 tot en met 2016 (vijfjaarsperiode), op basis van de jaarrekeningen over deze periode. De uitkomsten van ons empirisch onderzoek presenteren wij in de volgende paragrafen.

\subsection{Onderzoeksresultaten kwaliteit verslaggeving}

Zoals gezegd, richten wij ons allereerst op de aard en omvang van de toelichting op accountantshonoraria in de jaarverslaggeving 2016 om ons zo een oordeel te vormen over de kwaliteit van de toelichting. De belangrijkste uitkomsten zijn samengevat in tabel 3.

Alle onderzochte ondernemingen hebben een toelichting op de accountantshonoraria in de zin van artikel 2:382a BW opgenomen in de jaarrekening 2016. Het merendeel van deze ondernemingen presenteert deze toelichting in tabelvorm (92\%) en laat ook vergelijkende cijfers zien (99\%). Verder vinden we in alle gevallen (100\%) een vermelding van het honorarium voor de controle van de jaarrekening dat ten laste is gekomen van de rechtspersoon. Ook voor andere controleopdrachten wordt het honorarium veelal vermeld (91\%). De vermelding van honoraria voor adviesdiensten op fiscaal terrein (72\%) of voor andere niet-controlediensten $(76 \%)$ zien we minder vaak terug in de jaarreke- ningen. Bij het niet vermelden van deze honoraria is het ons niet expliciet duidelijk of dit type dienstverlening niet heeft plaatsgevonden in het boekjaar of dat de honoraria ten onrechte niet zijn vermeld. Om duidelijkheid te geven verdient het volgens ons aanbeveling om de totale tabel op te nemen; voor dienstverlening die niet heeft plaatsgevonden kan bij het honorarium dan 'EUR 0' of 'nihil' worden vermeld.

Een eerste voorbeeld van een toelichting op accountantshonoraria is opgenomen in figuur 1 en betreft de jaarrekening van Philips. De toelichting is weliswaar niet opgesteld volgens de aanbevolen tabelvorm van NIVRA-Wijzer 1 (zie tabel 1), maar bevat toch een aantal positieve aspecten. In de toelichting komen de vier verschillende typen dienstverlening (controle jaarrekening, andere controleopdrachten, fiscale adviesdiensten en overige niet-controlediensten) expliciet terug. Er wordt zelfs een iets meer verfijnde uitsplitsing gemakkt, waarbij bijvoorbeeld voor de controle van de jaarrekening onderscheid wordt gemaakt tussen de geconsolideerde jaarrekening en de statutaire jaarrekening. Verder is positief dat de honoraria voor drie boekjaren worden vermeld; dit biedt inzicht in de ontwikkeling van de accountantshonoraria over meerdere jaren. Tot slot mag duidelijk zijn dat het effect van artikel $24 \mathrm{~b}$ Wta zich doet gelden in deze toelichting. Vergoedingen uit niet-controleopdrachtgerelateerde diensten zijn aanzienlijk afgenomen, waarbij wel opvalt dat de totale hoogte van het honorarium ten opzichte van 2014 redelijk stabiel is gebleven. De in 2015 geëntameerde afsplitsing van Philips Lighting uit de groep zal naar alle waarschijnlijkheid reden zijn van de aanzienlijke stijging van het honorarium uit hoofde van acquisitions and divestments in het boekjaar 2015 .

Als we vervolgens de aard en inhoud van de toelichting nader beschouwen, zien we een wat wisselend beeld. Van de 75 ondernemingen geven er 55 (73\%) aan of de

Tabel 2 Kenmerken van de onderzoekspopulatie eind 2016 in EUR '000

\begin{tabular}{|c|c|c|c|c|c|}
\hline Index & $\begin{array}{l}\text { Aantal onderzochte } \\
\text { ondernemingen }\end{array}$ & & $\begin{array}{l}\text { Balanstotaal onderzochte } \\
\text { ondernemingen }\end{array}$ & Omzet & $\begin{array}{l}\text { Resultaat voor } \\
\text { belasting }\end{array}$ \\
\hline \multirow{3}{*}{ AEX } & \multirow{3}{*}{25} & Gemiddelde & 107.972 .833 & 24.206 .086 & 1.610 .317 \\
\hline & & Maximum & 845.081 .000 & 221.911 .450 & 7.469 .000 \\
\hline & & Minimum & 1.083 .338 & 151.612 & -2.039 .200 \\
\hline \multirow{3}{*}{ AMX } & \multirow{3}{*}{25} & Gemiddelde & 8.789 .824 & 3.279 .172 & 195.862 \\
\hline & & Maximum & 76.396 .800 & 24.846 .000 & 838.000 \\
\hline & & Minimum & 587.569 & 89.469 & -291.831 \\
\hline \multirow{3}{*}{ AScX } & \multirow{3}{*}{25} & Gemiddelde & 1.320 .583 & 528.906 & 13.312 \\
\hline & & Maximum & 14.877 .411 & 2.108.962 & 85.785 \\
\hline & & Minimum & 22.366 & - & -103.802 \\
\hline
\end{tabular}




\section{Tabel 3 Kwaliteit van de toelichting op de accountantshonoraria}

\begin{tabular}{|c|c|c|c|c|}
\hline \multirow{2}{*}{$\begin{array}{l}\text { Toelichting } \\
(\mathrm{n}=75)\end{array}$} & \multicolumn{4}{|c|}{2016} \\
\hline & Ja & $\%$ & Nee & $\%$ \\
\hline \multicolumn{5}{|l|}{ Vermeldt de rechtspersoon de in het boekjaar 2016 ten laste van de rechtspersoon gebrachte totale honoraria voor: } \\
\hline - het onderzoek van de jaarrekening & 75 & 100 & 0 & 0 \\
\hline - andere controleopdrachten & 68 & 91 & 7 & 9 \\
\hline - adviesdiensten op fiscaal terrein & 54 & 72 & 21 & 28 \\
\hline - andere niet-controlediensten & 57 & 76 & 18 & 24 \\
\hline Worden bovenstaande gegevens in tabelvorm opgenomen en gepresenteerd? & 69 & 92 & 6 & 8 \\
\hline Worden voor de bovenstaande gegevens ook de vergelijkende cijfers over het voorgaande boekjaar verstrekt? & 74 & 99 & 1 & 1 \\
\hline $\begin{array}{l}\text { Wordt toegelicht of de vermelde kosten betrekking hebben op alleen de externe accountant en zijn accountantsorgani- } \\
\text { satie, of dat alle honoraria van het betreffende netwerk van de accountantsorganisatie zijn opgenomen? }\end{array}$ & 55 & 73 & 20 & 27 \\
\hline $\begin{array}{l}\text { Worden cijfermatig zowel de honoraria voor de accountantsorganisatie zelf (bijv. PricewaterhouseCoopers Accountants } \\
\text { N.V.) als de honoraria voor het gehele netwerk van de accountantsorganisatie benoemd? }\end{array}$ & 42 & 56 & 33 & 44 \\
\hline $\begin{array}{l}\text { Wordt in de toelichting van de jaarrekening uiteengezet welke methode van vermelding van de totale honoraria voor het } \\
\text { onderzoek van de jaarrekening is gehanteerd? }\end{array}$ & 20 & 27 & 55 & 73 \\
\hline $\begin{array}{l}\text { Wordt toegelicht of de honoraria met betrekking tot dochtermaatschappijen en met betrekking tot andere maatschappijen } \\
\text { waarvan de financiële gegevens worden meegeconsolideerd zijn begrepen in de opgave van de accountantshonoraria? }\end{array}$ & 36 & 48 & 39 & 52 \\
\hline $\begin{array}{l}\text { Indien een materieel deel van de in de consolidatie begrepen dochtermaatschappijen door een andere externe accoun- } \\
\text { tant en accountantsorganisatie dan de in artikel 2:382a lid } 1 \text { BW bedoelde worden onderzocht, wordt van dit feit mel- } \\
\text { ding gemaakt en zijn de daaraan gerelateerde honoraria op vergelijkbare wijze in de toelichting opgenomen? }(n=55)\end{array}$ & 24 & 44 & 31 & 56 \\
\hline Wordt een kwalitatieve toelichting gegeven op de accountantshonoraria? & 27 & 36 & 48 & 64 \\
\hline
\end{tabular}

vermelde accountantshonoraria betrekking hebben op alleen de externe accountant en zijn accountantsorganisatie, of dat alle honoraria van het betreffende netwerk van de accountantsorganisatie zijn opgenomen. Hierbij presenteren 42 ondernemingen (56\%) ook daadwerkelijk een cijfermatige uitsplitsing. Hierbij worden veelal twee kolommen gehanteerd, waarbij onderscheid wordt gemaakt tussen honoraria voor de accountantsorganisatie enerzijds en honoraria voor andere onderdelen binnen het netwerk van de accountantsorganisatie anderzijds. Het is gezien het belang van deze informatie opmerkelijk dat slechts iets meer dan de helft van de onderzochte ondernemingen deze uitsplitsing opneemt. Vergoedingen die niet aan de accountantsorganisatie zelf toekomen, maar bijvoorbeeld aan een gelieerde vestiging in het buitenland, kunnen evenzeer een bedreiging voor de onafhankelijkheid van de externe accountant vormen.

Een ander belangrijk element van de toelichting op accountantshonoraria is de vermelding van de methode van toerekening zoals in de vorige paragraaf aangegeven. Dit is van belang omdat in de praktijk meerdere methodes gehanteerd worden en artikel 2:382a van het Burgerlijk Wetboek hier geen duidelijkheid biedt. Zoals vermeld in paragraaf 2.1, beveelt RJ 390 wel een specifieke methode aan, en wel om de vermelde accountantshonoraria te koppelen aan de controleopdracht ongeacht wanneer werkzaamheden heb-

\section{Figuur 1 Toelichting accountantshonoraria; Philips, Jaarrekening 2016, p. 124}

\section{Audit fees}

The table below shows the fees attributable to the fiscal years 2014, 2015 and 2016 for services rendered by the respective Group auditors.

Philips Group

Fees in millions of EUR

$2014-2016$

\begin{tabular}{|c|c|c|c|}
\hline & 2014 & 2015 & 2016 \\
\hline Audit fees & 14.9 & 15.3 & 16.8 \\
\hline - consolidated financial statements & 9.6 & 9.8 & 12.1 \\
\hline - statutory financial statements & 5.3 & 5.5 & 4.7 \\
\hline Audit-related fees & 3.9 & 4.9 & 2.3 \\
\hline - acquisitions and divestments & 2.4 & 3.6 & 0.9 \\
\hline - sustainability assurance & 0.6 & 0.6 & 0.7 \\
\hline - other & 0.9 & 0.7 & 0.7 \\
\hline Tax fees & 0.2 & 1.1 & 0.0 \\
\hline - tax compliance services & 0.2 & 1.1 & 0.0 \\
\hline All other fees & 0.0 & 0.0 & 0.0 \\
\hline - other & 0.0 & 0.0 & 0.0 \\
\hline Fees $^{1)}$ & 19.0 & 21.3 & 19.1 \\
\hline
\end{tabular}

1) Fees charged by the Dutch organization of the Philips Group auditor were EUR 9.8 million in 2016

ben plaatsgevonden. Tevens is in RJ 390 een stellige uitspraak opgenomen dat in ieder geval de gebruikte methode toegelicht dient te worden. Gezien het voorgaande is het opmerkelijk dat 55 van de 75 onderzochte ondernemingen (73\%) niet vermelden welke metho- 
Figuur 2 Toelichting accountantshonoraria; Fugro, Jaarrekening 2016, p. 179

\subsection{Audit fees}

With reference to Section 2:382a of the Netherlands Civil Code, the following fees for the financial year have been charged by EY (2015: KPMG) to the company and its subsidiaries:

$(\operatorname{EUR} \times 1,000)$

2016

2015

\begin{tabular}{lrrrrrr}
\hline & $\begin{array}{r}\text { Ernst \& Young } \\
\text { Accountants } \\
\text { LLP }\end{array}$ & $\begin{array}{r}\text { Other EY } \\
\text { network }\end{array}$ & $\begin{array}{r}\text { KPMG } \\
\text { Total EY }\end{array}$ & $\begin{array}{r}\text { Other } \\
\text { Accountants } \\
\text { N.V. }\end{array}$ & $\begin{array}{r}\text { KPMG } \\
\text { network }\end{array}$ & $\begin{array}{r}\text { Total } \\
\text { KPMG }\end{array}$ \\
\hline Statutory audit of financial statements & 1,470 & 2,215 & 3,685 & 1,805 & 1,232 & 3,037 \\
\hline Other assurance services & - & 86 & 86 & - & 31 & 31 \\
\hline Tax advisory services & - & 902 & 902 & - & 43 & 43 \\
\hline Other non-audit services & - & 72 & 72 & - & - & - \\
\hline Total & 1,470 & 3,275 & 4,745 & 1,805 & 1,306 & 3,111 \\
\hline
\end{tabular}

Tax advisory services primarily consist of tax compliance work. The majority of tax advisory fees incurred in 2016 relate to prior tax years. With the appointment of EY as auditor, the provision of non-assurance services is significantly reduced, in accordance with Fugro's global independence policy. Audit and (non-)audit related fees for the respective years are charged to the income statement on an accrual basis.

The fees paid for the above mentioned services, which are included in profit or loss of the consolidated financial statements in the line other expenses, are evaluated on a regular basis and in line with the market.

de van toerekenen is gehanteerd. Wij menen dat het (inmiddels) gangbaar is om de door de RJ aanbevolen methode te hanteren, maar ter voorkoming van onduidelijkheid is het volgens ons belangrijk dat dit wordt geëxpliciteerd in de toelichting. Figuur 2 bevat een voorbeeld uit de jaarrekening 2016 van Fugro waarin wel wordt toegelicht dat accountantshonoraria op basis van het toerekeningsprincipe (accrual basis) worden vermeld.

Vergelijkbaar met bovenstaande constatering, zien we ook dat ondernemingen slechts beperkt expliciteren of accountantshonoraria van dochtermaatschappijen en maatschappijen die worden meegeconsolideerd zijn begrepen in de vermelding van de accountantshonoraria in de geconsolideerde jaarrekening. Ook hier is het aantal jaarrekeningen waarin deze vermelding ontbreekt, namelijk 39 (52\%), opvallend hoog. Het valt op dat ondernemingen die opgenomen zijn in de AEX deze toelichting vaker opnemen $(60 \%)$ dan ondernemingen die opgenomen zijn in de AMX (52\%) of AScX $(32 \%)$. Indien een materieel deel van de in de meegeconsolideerde dochtermaatschappijen door een andere externe accountant dan de accountant van de moedermaatschappij wordt gecontroleerd, verdient het aanbeveling om van dit feit melding te maken en de daaraan gerelateerde honoraria op vergelijkbare wijze in de toelichting op te nemen. Ook deze vermelding zien we relatief weinig expliciet terug in de jaarrekeningen, namelijk in 24 van de 55 jaarrekeningen (44\%).

Figuur 3 bevat een voorbeeld van de toelichting op ac- countantshonoraria van ASML met een aantal positieve elementen. De toelichting bevat een duidelijke tabel, waarbij de honoraria voor de verschillende typen dienstverlening worden uitgesplitst. Tevens worden deze honoraria onderverdeeld naar de accountantsorganisatie zelf en het netwerk van de accountant. De toelichting bevat tevens een heel duidelijke omschrijving van de werkzaamheden die de accountant heeft verricht en die dus deel uitmaken van de honoraria. Uit de toelichting blijkt expliciet dat ook de werkzaamheden van de accountant voor statutaire doeleinden en voor wettelijke rapportages van dochtermaatschappijen zijn meegenomen.

Een ander voorbeeld is opgenomen in figuur 4, afkomstig uit de jaarrekening 2016 van Heineken. In deze toelichting wordt duidelijk benoemd dat de honoraria zowel betrekking hebben op controlewerkzaamheden voor de moeder-als voor dochtermaatschappijen. Daarnaast wordt toegelicht welke diensten zijn opgenomen onder de overige controlediensten ('Other audit services'). Ook wordt benoemd dat door de accountant weliswaar fiscale diensten en overige niet-controlediensten zijn verleend, maar dat dit is toegestaan op basis van lokale onafhankelijkheidsregelgeving. Tot slot meldt Heineken dat de vergelijkende cijfers voor accountantshonoraria zijn aangepast naar aanleiding van controlewerkzaamheden die in 2016 zijn afgerond, maar betrekking hadden op boekjaar 2015 (de jaarrekening 2015 laat een totaalbedrag van EUR 8,7 miljoen aan accountantshonoraria zien). 


\section{Figuur 3 Toelichting accountantshonoraria; ASML, Jaarrekening 2016, p. 52-53}

\section{Principal Accountant Fees and Services}

KPMG has served as our independent registered public accounting firm for the year ending December 31, 2016. The following table sets out the aggregate fees for professional audit services and other services rendered by KPMG and their member firms and/ or affiliates in 2016:

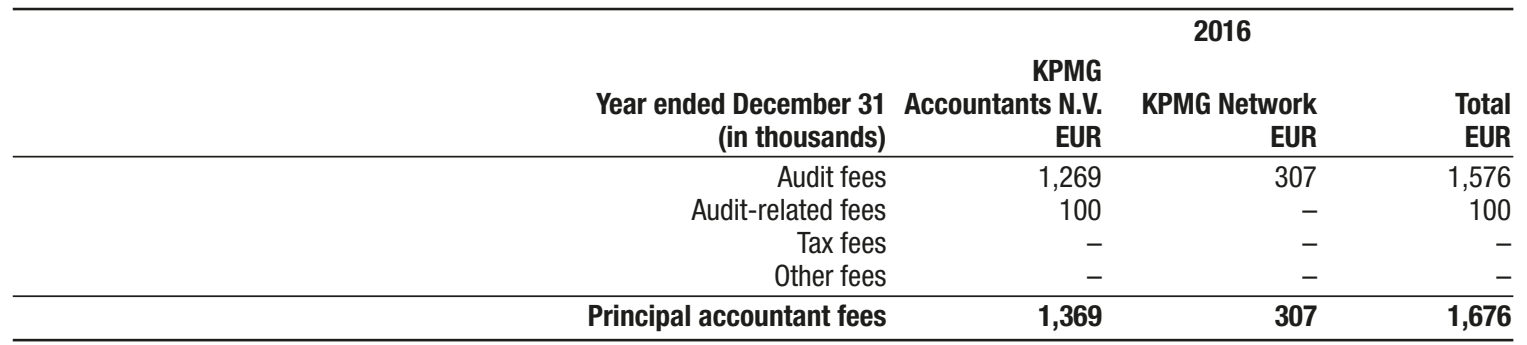

\section{Audit fees and audit-related fees}

Audit fees primarily relate to the audit of the Financial Statements as set out in this Annual Report, our Statutory Annual Report, limited procedures on our quarterly results, certain agreed-upon procedures on the targets achieved in order for the RC to assess compliance with the Remuneration Policy and services related to our statutory and regulatory filings of our subsidiaries. Audit-related fees relate to sustainability assurance services and other permissible non-audit services.

The AC has approved the external audit plan and audit fees for the year 2016.

Deloitte has served independent registered public accounting firm for the year ending December 31, 2015. The following table sets out the aggregate fees for professional audit services and other services rendered by Deloitte and their member firms and/or affiliates in 2015:

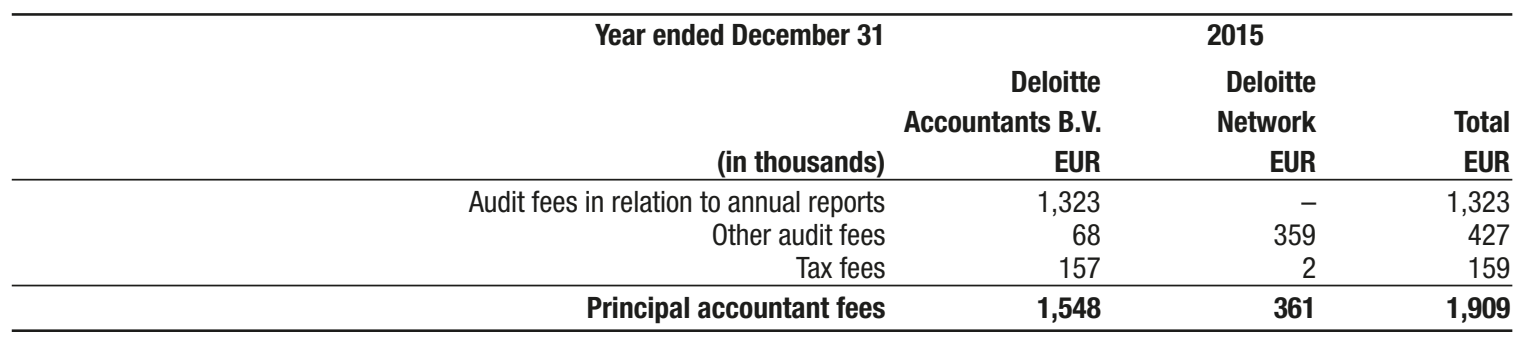

\section{Audit fees in relation to annual reports and other audit fees}

Audit fees primarily relate to the audit of the Financial Statements as set out in this Annual Report, our Statutory Annual Report, limited procedures on our quarterly results, agreed upon procedures related to our Remuneration Report and services related to our statutory and regulatory filings and our subsidiaries.

\section{Tax fees}

The tax fees include tax compliance services and tax advisory services.

The AC monitors compliance with the Dutch and US rules on non-audit services provided by an independent registered public accounting firm, which outlines strict separation of audit and advisory services for Dutch public interest entities.

Al met al bevat deze ogenschijnlijk beknopte toelichting dus veel relevante informatie voor de gebruiker.

Tot slot hebben we geanalyseerd in welke mate ondernemingen een kwalitatieve toelichting opnemen op de ontwikkeling in de hoogte en/of samenstelling van accountantshonoraria. Slechts 27 van de 75 ondernemingen $(36 \%)$ neemt een dergelijke toelichting op. Ook hier geldt weer dat AEX-ondernemingen beter scoren dan de overige onderzochte ondernemingen. Van de AEX-ondernemingen hebben 15 ondernemingen (60\%) een kwalitatieve toelichting opgenomen op de ontwikkeling in accountantshonoraria. Bij AMX- en AScXondernemingen ligt dit beduidend lager, van de 25 ondernemingen opgenomen in de AMX en AScX hebben maar zes AMX-ondernemingen (24\%) en vijf AScX-ondernemingen (20\%) een kwalitatieve toelichting op accountantshonoraria opgenomen in hun jaarrekening. 


\section{Figuur 4 Toelichting accountantshonoraria; Heineken, Jaarrekening 2016, p. 132}

\section{Auditor fees}

Other expenses in the consolidated financial statements include EUR 9.8 million of fees in 2016 for services provided by Deloitte Accountants B.V. and its member firms and/or affiliates (2015: EUR 9.5 million). Fees for audit services include the audit of the financial statements of the Company and its subsidiaries. Fees for other audit services include review of interim financial statements, sustainability, subsidy and other audits. Fees for tax services include tax compliance and tax advice. Fees for other non-audit services include agreed-upon procedures and advisory services. Fees for tax and other non-audit services are related to the network outside the Netherlands and are in accordance with local independence regulation.

Comparative numbers have been revised for the effect of audit activities applicable to 2015 that have been finalised in 2016 .

\begin{tabular}{lrrrrrr} 
& $\begin{array}{r}\text { Deloitte } \\
\text { Accountants B.V. }\end{array}$ & $\begin{array}{r}\text { Deloitte } \\
\text { Accountants B.V. }\end{array}$ & $\begin{array}{r}\text { Other Deloitte } \\
\text { member firms } \\
\text { and affiliates }\end{array}$ & $\begin{array}{r}\text { Other Deloitte } \\
\text { member firms } \\
\text { and affiliates }\end{array}$ & 2015 & 2016 \\
\hline In millions of EUR & 2016 & 2015 & 2016 & 2015 \\
\hline Audit of HEINEKEN and its subsidiaries & 2.6 & 2.7 & 6.2 & 5.9 & 8.8 & 8.6 \\
\hline Other audit services & 0.4 & 0.4 & 0.3 & 0.3 & 0.7 & 0.7 \\
\hline Tax services & - & - & 0.1 & 0.2 & 0.1 & 0.2 \\
\hline Other non-audit services & - & - & 0.2 & - & 0.2 & - \\
\hline Total & 3.0 & 3.1 & 6.8 & 6.4 & 9.8 & 9.5 \\
\hline
\end{tabular}

Alhoewel de toelichting op de accountantshonoraria voor verbetering vatbaar is, is er een kleine verbetering in kwaliteit zichtbaar als we onze resultaten vergelijken met de resultaten van Langendijk (2011). Langendijk vindt dat 49 van de 70 onderzochte beursgenoteerde ondernemingen (70\%) netwerkinformatie geeft, waarvan 31 een cijfermatige uitsplitsing publiceren (44\%). Wij vinden dat 55 van de 75 onderzochte ondernemingen (73\%) netwerkinformatie geeft, waarvan 42 een cijfermatige uitsplitsing publiceren (56\%). Daarnaast vermeldt Langendijk dat maar $1 \%$ van de ondernemingen een toelichting geeft op hoogte of ontwikkeling van de accountantshonoraria, terwijl dat in onze onderzoekspopulatie 36\% is. Verdere vergelijkingen zijn moeilijk te maken omdat Langendijk geen uitsplitsing maakt tussen beursgenoteerde ondernemingen en niet-beursgenoteerde ondernemingen.

\subsection{Onderzoeksresultaten ontwikkeling accountantshonoraria}

In deze paragraaf gaan we nader in op de ontwikkeling in de hoogte van de accountantshonoraria. Tabel 4 bevat een totaaloverzicht van de hoogte en samenstelling van de accountantshonoraria voor 2016, uitgesplitst naar ondernemingen per index (AEX, AMX, AScX). In totaal is er in 2016 bijna EUR 329 miljoen aan accountantshonoraria betaald door de 75 beursgenoteerde ondernemingen. Logischerwijs heeft het grootste deel van dit bedrag, namelijk EUR 255 miljoen, betrekking op ondernemingen opgenomen in de AEX. Dit zijn grotere en (veelal) meer complexe ondernemingen, wat zich weerspiegelt in hogere accountantshonoraria. Het is ook interessant te bezien op welke diensten van de accountant de honoraria betrekking hebben. Uit tabel 4 blijkt dat de accountantshonoraria in grote mate be- trekking hebben op het onderzoek (ofwel de controle) van de jaarrekening. Voor ondernemingen in de AEX en AMX is dit zelfs bijna $90 \%$ van de totale accountantshonoraria. Voor AScX-ondernemingen ligt dit percentage wat lager (74\%). Het procentuele aandeel van honoraria voor fiscale dienstverlening en andere niet-controlediensten, van AEX-ondernemingen, ten opzichte van de totale accountantshonoraria is met $1 \%$ respectievelijk 2\% laag te noemen. Deze percentages stijgen naar respectievelijk $3 \%$ en $1 \%$ voor AMX-ondernemingen en naar $4 \%$ en $4 \%$ voor AScX-ondernemingen. De percentages zijn nog steeds laag te noemen en de absolute bedragen zijn ook laag, zoals te zien is in tabel 4.

In onze populatie zijn 62 ondernemingen opgenomen die over de periode 2012 tot en met 2016 aan de beurs genoteerd stonden. Voor deze ondernemingen is inzichtelijk gemaakt welke ontwikkeling is waar te nemen in de hoogte en samenstelling van de accountantshonoraria over deze onderzoeksperiode. Uit tabel 5 blijkt dat de gemiddelde honoraria voor accountantsdiensten zijn afgenomen van ongeveer EUR 5,0 miljoen in 2012 tot ongeveer EUR 4,5 miljoen in 2016 voor de betreffende 62 ondernemingen. Dit is een daling van ruim $11 \%$ over een periode van vijf jaar. Uit tabel 5 is verder op te maken dat de kosten van het onderzoek van de jaarrekening schommelen rond een gemiddelde van EUR 3,9 miljoen. Het verschil tussen 2012 en 2016 is zeker niet opmerkelijk te noemen (3\% stijging). De daling van de gemiddelde honoraria wordt vooral veroorzaakt door een grote reductie van de honoraria van alle overige diensten die door de controlerende accountant worden verleend. Voor de con- 
Tabel 4 Samenstelling accountantshonorarium 2016 in EUR '000

\begin{tabular}{|c|c|c|c|c|c|c|c|c|c|}
\hline \multirow{2}{*}{$\begin{array}{l}\text { Hoogte accountants- } \\
\text { honorarium } 2016 \\
(n=75)\end{array}$} & & \multicolumn{2}{|c|}{ AEX } & \multicolumn{2}{|c|}{ AMX } & \multicolumn{2}{|c|}{$A S c X$} & \multicolumn{2}{|c|}{ Totaal } \\
\hline & & Bedrag & $\%$ & Bedrag & $\%$ & Bedrag & $\%$ & Bedrag & $\%$ \\
\hline \multirow{3}{*}{$\begin{array}{l}\text { Onderzoek van de jaarre- } \\
\text { kening }\end{array}$} & Gemiddelde & 9.133 & 89 & 2.021 & 89 & 517 & 74 & 11.671 & 89 \\
\hline & Maximum & 46.550 & & 5.900 & & 1.857 & & & \\
\hline & Minimum & 515 & & 118 & & 69 & & & \\
\hline \multirow{3}{*}{$\begin{array}{l}\text { Andere controleopdrach- } \\
\text { ten }\end{array}$} & Gemiddelde & 785 & 8 & 147 & 7 & 127 & 18 & 1.059 & 8 \\
\hline & Maximum & 3.000 & & 900 & & 879 & & & \\
\hline & Minimum & - & & - & & - & & & \\
\hline \multirow{3}{*}{$\begin{array}{l}\text { Adviesdiensten op fiscaal } \\
\text { terrein }\end{array}$} & Gemiddelde & 68 & 1 & 65 & 3 & 28 & 4 & 161 & 1 \\
\hline & Maximum & 472 & & 902 & & 304 & & & \\
\hline & Minimum & - & & - & & - & & & \\
\hline \multirow{3}{*}{$\begin{array}{l}\text { Andere niet-controledien- } \\
\text { sten }\end{array}$} & Gemiddelde & 217 & 2 & 27 & 1 & 24 & 4 & 268 & 2 \\
\hline & Maximum & 2.600 & & 191 & & 444 & & & \\
\hline & Minimum & - & & - & & - & & & \\
\hline Totaal & & 10.203 & 100 & 2.260 & 100 & 696 & 100 & 13.159 & 100 \\
\hline
\end{tabular}

\section{Tabel 5 Ontwikkeling accountantshonoraria 2012-2016 in EUR '000}

\begin{tabular}{|c|c|c|c|c|c|c|c|c|c|c|c|}
\hline \multirow{2}{*}{$\begin{array}{l}\text { Hoogte accountants- } \\
\text { honoraria ( } n=62 \text { ) }\end{array}$} & & \multicolumn{2}{|c|}{2016} & \multicolumn{2}{|c|}{2015} & \multicolumn{2}{|c|}{2014} & \multicolumn{2}{|c|}{2013} & \multicolumn{2}{|c|}{2012} \\
\hline & & Bedrag & $\%$ & Bedrag & $\%$ & Bedrag & $\%$ & Bedrag & $\%$ & Bedrag & $\%$ \\
\hline \multirow{3}{*}{$\begin{array}{l}\text { Onderzoek van de } \\
\text { jaarrekening }\end{array}$} & Gemiddelde & 4.003 & 90 & 3.858 & 87 & 4.022 & 85 & 3.731 & 79 & 3.895 & 77 \\
\hline & Maximum & 46.550 & & 47.430 & & 41.500 & & 33.580 & & 34.960 & \\
\hline & Minimum & 115 & & 115 & & 80 & & 80 & & 85 & \\
\hline \multirow{3}{*}{$\begin{array}{l}\text { Andere } \\
\text { controleopdrachten }\end{array}$} & Gemiddelde & 307 & 7 & 359 & 8 & 356 & 7 & 491 & 10 & 610 & 12 \\
\hline & Maximum & 3.000 & & 2.300 & & 3.900 & & 4.500 & & 8.000 & \\
\hline & Minimum & - & & - & & - & & - & & - & \\
\hline \multirow{3}{*}{$\begin{array}{l}\text { Adviesdiensten } \\
\text { op fiscaal terrein }\end{array}$} & Gemiddelde & 56 & 1 & 116 & 3 & 290 & 6 & 351 & 8 & 332 & 7 \\
\hline & Maximum & 902 & & 1.224 & & 4.400 & & 3.200 & & 4.000 & \\
\hline & Minimum & - & & - & & - & & - & & - & \\
\hline \multirow{3}{*}{$\begin{array}{l}\text { Andere niet- } \\
\text { controlediensten }\end{array}$} & Gemiddelde & 104 & 2 & 88 & 2 & 83 & 2 & 148 & 3 & 202 & 4 \\
\hline & Maximum & 2.600 & & 2.700 & & 1.000 & & 1.400 & & 2.214 & \\
\hline & Minimum & - & & - & & - & & - & & - & \\
\hline Totaal & & 4.470 & 100 & 4.421 & 100 & 4.751 & 100 & 4.721 & 100 & 5.039 & 100 \\
\hline
\end{tabular}

trolerende accountant van een beursgenoteerde onderneming geldt in toenemende mate een exclusieve gerichtheid op de controle van de jaarrekening. De effecten van de implementatie van artikel $24 \mathrm{~b}$ van de Wta per 1 januari 2013 (zie paragraaf 2.2) doen zich nadrukkelijk gelden.

Hieruit volgt uiteraard dat de relatieve omvang van de honoraria voor het onderzoek (controle) van de jaarrekening ten opzichte van het totaal een sterk stijgend beeld laat zien. In 2012 had $77 \%$ van de totale accountantshonoraria betrekking op de controle van de jaarrekening, in 2016 is dit percentage gestegen tot 90 . We kunnen op basis van deze empirische data concluderen dat het beoogde doel van de wetgever, namelijk het 
waarborgen van de gepercipieerde onafhankelijkheid van de accountant, is gerealiseerd omdat het onderzoek van de jaarrekening een steeds groter deel van het totale accountantshonorarium uitmaakt. Dit betekent dat diensten naast de jaarrekeningcontrole verminderen, waardoor de accountant minder belangen hoeft mee te wegen in zijn oordeel omtrent de jaarrekening. In bijlage 3 is een uitsplitsing gemaakt naar index en wat opvalt, is dat de verhouding in de vergoeding voor de controle van de jaarrekening ten opzichte van de totale accountantshonoraria het hoogst is bij AEX-ondernemingen (90\%) en het laagst bij AScX-ondernemingen (80\%). Dit indiceert dat de governancegremia (bijvoorbeeld het audit committee) van AEX-ondernemingen hier strenger op toezien dan die bij de kleinere beursondernemingen. Ook is mogelijk dat de accountantsorganisaties zelf voorzichtiger zijn om overige diensten bij AEX-ondernemingen aan te bieden (ook al is het toegestaan), gezien de maatschappelijke aandacht voor deze ondernemingen. We achten de eerste reden het meest plausibel, gegeven het stringente 'independence-beleid' dat audit committees voor hun controlerend accountant hebben geformuleerd. Een illustratie hiervan is ook opgenomen in figuur 2 .

Als laatste onderdeel van ons empirisch onderzoek beschouwen we de effecten van accountantskantoorroulaties op de accountantshonoraria. Tabel 6 laat zien dat de accountantskantoorroulaties voornamelijk in de boekjaren 2014, 2015 en 2016 hebben plaatsgevonden. Vooral in boekjaar 2016 hebben veel roulaties plaatsgevonden (25). Zoals in de inleiding aangegeven, is dit het resultaat van het aan het eind van 2012 aangenomen amendement Van Vliet dat Nederlandse OOB's dwong om uiterlijk 1 januari 2016 een nieuwe accountant te benoemen. Overigens blijkt uit de evaluatie van de jaarverslagen en aandeelhoudersvergaderingen die Eumedion (2017) heeft uitgevoerd dat 23 beursgenoteerde ondernemingen van accountant zijn gewisseld in 2016. Het verschil met de 25 ondernemingen uit ons empirisch onderzoek wordt waarschijnlijk veroorzaakt door een verschillende verwerkingswijze van twee ondernemingen die een gebroken boekjaar kennen. Gecorrigeerd voor dit effect zijn de onderzoeksresultaten dus consistent met elkaar.
Tabellen 7 en 8 illustreren de effecten van de accountantskantoorroulaties in de boekjaren 2016 en 2015 op de hoogte van de accountantshonoraria. Uit het onderzoek blijkt dat de accountantshonoraria voor AEXondernemingen in het eerste jaar na de accountantskantoorroulaties lager zijn dan het voorgaande jaar terwijl de accountantshonoraria van ondernemingen die niet wisselen van accountant stijgt. Dit effect is zichtbaar in zowel boekjaar 2016 (25 accountantskantoorroulaties) als boekjaar 2015 (15 accountantskantoorroulaties). Uit de resultaten blijkt duidelijk dat de procentuele daling in 2015 sterker is dan in 2016.

Opvallend is dat de accountantskantoorroulaties zorgen voor een daling van de accountantshonoraria bij AEX-ondernemingen, maar dit effect is niet zichtbaar bij ondernemingen opgenomen in de AMX en AScX. Integendeel, bij deze ondernemingen zien we zowel in 2016 als 2015 een stijging van de honoraria na een accountantskantoorroulatie. Tabel 8 geeft een verdere verduidelijking. Te zien is dat bij het merendeel van de AEX-ondernemingen (bij 12 van de 16 ondernemingen) de accountantshonoraria dalen na een accountantsroulatie in 2016 en 2015. Bij ondernemingen die opgenomen zijn in de AMX en AscX zien we juist meer ondernemingen waarbij de accountantshonoraria stijgen na een roulatie in 2016 of 2015 . Dit fenomeen duiden wij als het 'trophy client'-effect. Accountantskantoren zijn bereid een hogere 'korting' te geven op accountantshonoraria om grote klanten aan zich te binden. Dit is immers goed voor de reputatie van een accountantskantoor. Een portfolio met aansprekende controlecliënten heeft ook een positieve invloed op de aantrekkelijkheid van accountantskantoren als werkgever. Daarnaast bieden grote controleklanten uiteraard schaal- en capaciteitsvoordelen. Het is voor ons niet mogelijk een eenduidige verklaring voor deze daling te geven. Overige verklaringen kunnen gelegen zijn in de 'scoping' van de auditdiensten. $\mathrm{Na}$ een kantoorroulatie kan er sprake zijn van een beperktere scope van de controle. ${ }^{8}$

Het door ons waargenomen effect wordt in de literatuur bevestigd door Köhler en Ratzinger (2012). Zij vinden geen empirisch bewijs voor een significante verlaging van accountantshonoraria na een accountantskantoorroulatie bij kleinere ondernemingen, maar wel empirisch bewijs voor grotere ondernemingen.

Tabel 6 Kantoorroulatie uitgesplitst naar boekjaar

\begin{tabular}{|l|r|r|r|r|r|}
\hline Aantal roulaties per boekjaar $(n=75)$ & 2016 & 2015 & 2014 & 2013 & 2012 \\
\hline AEX & 9 & 7 & 4 & 0 & 0 \\
\hline AMX & 10 & 5 & 2 & 0 & 0 \\
\hline AScX & 6 & 3 & 5 & 1 & 0 \\
\hline Totaal & 25 & 15 & 11 & 1 & 0 \\
\hline
\end{tabular}


Tabel 7 Effect accountantskantoorroulatie op accountantshonoraria

\begin{tabular}{|c|c|c|c|c|}
\hline $\begin{array}{l}\text { Effect kantoorroulatie op audit } \\
\text { fee }(n=25)\end{array}$ & 2016 & 2015 & $\begin{array}{c}\text { Effect t.0.v. } \\
\text { voorgaand jaar }\end{array}$ & $\begin{array}{l}\text { Procentueel } \\
\text { effect }\end{array}$ \\
\hline AEX & 13.013 & 13.520 & -507 & $-4 \%$ \\
\hline AMX & 1.647 & 1.459 & 188 & $13 \%$ \\
\hline AScX & 606 & 530 & 76 & $14 \%$ \\
\hline Totaal & 15.265 & 15.509 & -243 & $-2 \%$ \\
\hline $\begin{array}{l}\text { Effect kantoorroulatie op audit } \\
\text { fee }(n=15)\end{array}$ & 2015 & 2014 & $\begin{array}{l}\text { Effect t.0.v. } \\
\text { voorgaand jaar }\end{array}$ & $\begin{array}{l}\text { Procentueel } \\
\text { effect }\end{array}$ \\
\hline AEX & 3.512 & 4.779 & -1.267 & $-27 \%$ \\
\hline AMX & 1.140 & 938 & 203 & $22 \%$ \\
\hline AScX & 332 & 302 & 30 & $10 \%$ \\
\hline Totaal & 4.985 & 6.018 & -1.034 & $-17 \%$ \\
\hline
\end{tabular}

\section{Tabel 8 Effect accountantskantoorroulatie op accountantshonoraria in aantallen}

\begin{tabular}{|c|c|c|c|c|}
\hline $\begin{array}{l}\text { Effect kantoorroulatie } \\
2016(n=25)\end{array}$ & $\begin{array}{l}<-10 \% \\
\text { (daling honorarium) }\end{array}$ & $\begin{array}{l}-10 \% \text { tot } 0 \% \\
\text { (daling honorarium) }\end{array}$ & $\begin{array}{l}0 \% \text { tot } 10 \% \\
\text { (stijging honorarium) }\end{array}$ & $\begin{array}{l}>10 \% \\
\text { (stjjging honorarium) }\end{array}$ \\
\hline AEX & 2 & 4 & 2 & 1 \\
\hline AMX & 3 & 1 & 1 & 5 \\
\hline AScX & 2 & 1 & 1 & 2 \\
\hline $\begin{array}{l}\text { Totaal aantal } \\
\text { ondernemingen }\end{array}$ & 7 & 6 & 4 & 8 \\
\hline $\begin{array}{l}\text { Effect kantoorroulatie } \\
2015(n=15)\end{array}$ & $\begin{array}{l}<-10 \% \text { (daling } \\
\text { honorarium) }\end{array}$ & $\begin{array}{l}-10 \% \text { tot } 0 \% \text { (daling } \\
\text { honorarium) }\end{array}$ & $\begin{array}{l}0 \% \text { tot } 10 \% \\
\text { (stijging honorarium) }\end{array}$ & $>10 \%$ (stijging honorarium) \\
\hline AEX & 6 & 0 & 1 & 0 \\
\hline AMX & 1 & 1 & 0 & 3 \\
\hline $\operatorname{ASc} X$ & 0 & 1 & 1 & 1 \\
\hline $\begin{array}{l}\text { Totaal aantal } \\
\text { ondernemingen }\end{array}$ & 7 & 2 & 2 & 4 \\
\hline
\end{tabular}

De resultaten van ons onderzoek tonen samenvattend geen eenduidig beeld over de effecten van een accountantskantoorroulatie op de accountantshonoraria. Dit wisselende beeld uit de resultaten is consistent met resultaten uit eerder academisch onderzoek. Verschillende onderzoeken tonen aan dat honoraria na accountantskantoorroulatie dalen (zie onder andere Ettredge \& Greenberg, 1990; Köhler et al., 2010), terwijl andere onderzoeken dit effect niet vinden (Bigus \& Zimmermann, 2009; Langendijk, 2011). Dit wisselende beeld volgt ook uit de metastudie uitgevoerd door Hay, Knechel en Wong (2006).

We merken ten slotte op dat de uitkomsten van bovengenoemde onderzoeken sterk verschillen qua onderzoekspopulatie en onderzoeksperiode en -duur, hetgeen waarschijnlijk mede ten grondslag ligt aan de diffuse resultaten van de gerefereerde onderzoeken. Bij de interpretatie van de onderzoeksresultaten dient hier op zorgvuldige wijze rekening mee te worden gehouden.

\section{CONCLUSIE EN NABESCHOUWING}

We kunnen stellen dat veel ondernemingen over het algemeen de uitsplitsing van de accountantshonoraria maken, wat de belangrijkste informatie is in de toelichting van het accountantshonoraria. Echter is de toelichting op de ontwikkeling en hoogte van de accountantshonoraria veelal summier. Daardoor is de informatie niet eenduidig te interpreteren en ook moeilijk te vergelijken met informatie van andere ondernemingen. Om de informatie over accountantshonoraria goed te interpreteren is het noodzakelijk te weten of deze betrekking heeft op alleen de accountantsorganisatie of ook op het netwerk van de accountantsorganisatie, of de honoraria met betrekking tot dochtermaatschappijen zijn inbegrepen en 
welke methode van toerekening van de accountantshonoraria is gehanteerd. Ook achten we nadere informatie over de aard van de verleende diensten van belang voor de belegger. Indien de governanceorganen een onafhankelijkheidsbeleid hebben ingevoerd met betrekking tot de controlerende accountant, raden wij aan dit ook te vermelden. Het zijn juist deze aspecten die veelal ontbreken in de toelichting en dat doet afbreuk aan de informatiewaarde van de toelichting voor gebruikers van de jaarrekening. Gezien de maatschappelijke aandacht voor accountantshonoraria is verbetering in de toelichting volgens ons dan ook zeker mogelijk en wenselijk.

Wat betreft de ontwikkeling van de honoraria valt op dat de totale honoraria voor accountantsdiensten zijn afgenomen van EUR 312 miljoen in 2012 tot EUR 277 miljoen in 2016 voor de 62 onderzochte ondernemingen. Dit effect is toe te schrijven aan de afname van de honoraria van overige diensten die het accountantskantoor naast de controleopdracht in rekening brengt. Een controlerende accountant is in zeer overwegende mate een 'audit only'-dienstverlener geworden. Het effect van wetgeving is duidelijk zichtbaar in deze trend. Het meest opmerkelijk is toch wel het 'trophy client'-effect: het fenomeen dat honoraria dalen bij een kantoorwisseling van een (zeer) grote controlecliënt. Ook hier is weer voorzichtigheid geboden in de analyse, want het bereik van de accountantscontrole (scope) kan zijn ingeperkt waardoor de vergelijkingsbasis over de jaren wegvalt. Uit onze eigen waarneming valt echter niet te ontkennen dat het 'trophy client'-effect ook bij gelijke scoping aanwezig is. Hier zijn dan ook plausibele verklaringen voor te geven. In Nederland is de spoeling immers dun en controleopdrachten van zeer grote ondernemingen zijn gewild bij de vier grote accountantsorganisaties. Daarbij speelt in Nederland ook mee dat binnen de sectoren slechts enkele grote spelers acteren. Een voorbeeld zijn de drie grootbanken in Nederland (ABN AMRO, ING en Rabobank). Verliest een kantoor een grootbank door de verplichte roulatie dan is het evident dat dit kantoor de controleopdracht van een andere grootbank graag wil winnen. $\mathrm{Al}$ is het alleen maar om de grote investeringen in sectorspecifieke kennis te behouden. Hier speelt uiteraard ook mee dat het winnen van grote controlecliënten van betekenis is voor de aantrekkelijkheid van het kantoor op de arbeidsmarkt. De vraag is uiteraard of de kwaliteit van de audits door deze ontwikkeling in gevaar wordt gebracht; lagere budgetten betekenen immers ook min- der controle-uren. Ook hier past ons weer bescheidenheid in de gevolgtrekkingen, omdat wij dit niet kunnen uitmaken in de door ons verzamelde gegevens.

Wat de vergelijkbaarheid van honoraria betreft, is het spijtig dat ondanks de veelstemmige kritiek op de wettekst vanuit de literatuur en het specifieke verzoek van de RJ, de Nederlandse wetgever de toelichtingseisen op de accountantshonoraria niet wil uitbreiden naar het gehele netwerk of netwerken die betrokken zijn bij de controle van de jaarrekening. Natuurlijk spelen hier overwegingen van administratieve lastenverzwaring mee en kan de weigering van de Nederlandse wetgever niet los worden gezien van de Europese Richtlijn. Echter, gezien het doel van de wetgever (het transparant maken van bedreigingen van de onafhankelijkheid van de accountant) zou een uitbreiding tot een drietal kolommen volgens ons toch proportioneel genoemd kunnen worden. Daarbij speelt mee dat de informatie toch alleszins eenvoudig te verzamelen zou moeten zijn (honoraria betaald aan netwerk X). Het laat zien dat een lobby voor een hogere kwaliteit van de wet niet vroeg genoeg kan beginnen. In dit geval al tijdens de totstandkoming van de Richtlijn 2006/43/EG door de Europese koepelorganisaties van bijvoorbeeld accountants en beleggers.

Naast de wetgever kan natuurlijk ook de 'markt' zelf een steentje bijdragen aan het verhogen van de verslaggevingskwaliteit ten aanzien van accountantshonoraria. Te denken valt aan vragen van organisaties die voor de belangen van beleggers opkomen. Door kritisch te zijn op hoogte en samenstelling van accountantshonoraria en relevante vragen te stellen tijdens bijvoorbeeld de algemene vergadering van aandeelhouders (AvA) of analistenbijeenkomsten krijgt het onderwerp vanzelf meer prioriteit. We hopen dat dit artikel aan deze kritische reflectie zal bijdragen.

Drs. W. (Wilfred) Kevelam RA is Senior Manager bij KPMG Financial Services (Utrecht) en als universitair docent Externe Verslaggeving verbonden aan de Rijksuniversiteit Groningen.

Prof. dr. R.L. (Ralph) ter Hoeven RA is partner op het vaktechnisch centrum van Deloitte Accountants en als hoogleraar Externe Verslaggeving verbonden aan de Rijksuniversiteit Groningen.

T.L. (Tristan) Brouwer MSc is student aan de Rijksuniversiteit Groningen. 
De maximale termijn voor de externe accountant is opgenomen in artikel 24 van de Wet toezicht accountantsorganisaties.

2. Richtlijn 78/660/EEG en Richtlijn 83/349/

EEG.

3 TK 31270, nr. 3, p. 26.

RJ-liting 2013-16, ten geleide.

Ondergeschikte accountantsorganisaties zijn organisaties die een deel van de controle verrichten van een concern, waarbij de accountantsor- ganisatie die de groep controleert de eindverantwoordelijkheid heeft voor de controle van de groepsjaarrekening.

6. NIVRA en NOvAA (2002), Nadere voorschriften inzake onafhankelijkheid van de accountant. - We gaan gezien het bestek van dit artikel niet nader in op wijzigingen die nadien zijn doorgevoerd in dit artikel.

8. Dat wil zeggen het doen uitvoeren van audits van lokale groepsonderdelen door lokale, niet aan de groepsaccountant verbonden accountantskantoren, respectievelijk het doen uitvoeren van statutaire audits door lokale, niet aan de groepsaccountant verbonden, accountantskantoren. Een wisseling van groepsaccountant is vaak ook aanleiding om deze scope van werkzaamheden van de groepsaccountant te herzien en het netwerk van de groepsaccountant bijvoorbeeld alleen voor de consolidatie significante entiteiten in te zetten.

\section{Literatuur}

- Bigus, J., \& Zimmermann, R.C. (2008). Nonaudit fees, market leaders and concentration in the German audit market: a descriptive analysis. International Journal of Auditing, 12(3): 159-179.

- Boonzaaijer, K.H., Lecq, S.G. van der, \& Veldhuizen, S. van (2014). Verplichte kantoorroulatie in de financiële sector. Maandblad voor Accountancy en Bedrijfseconomie, 88(9): 330-340.

- DeFond, M. L., Raghunandan, K., \& Subramanyam, K. R. (2002). Do non-audit service fees impair auditor independence? Evidence from going concern audit opinions. Journal of accounting research, 40(4): 1247-1274.

- Dieleman, A. (2008). Regelgeving mist doel door formulering wettekst. Accountancynieuws, 2008/19: 42-43.

— Ettredge, M., \& Greenberg, R. (1990). Determinants of fee cutting on initial audit engagements. Journal of Accounting Research, 28(1):
198-210.

n Eumedion (2017). Evaluation of the 2017 AGM season. Geraadpleegd op https://www. eumedion.n//n/public/kennisbank/avaevaluaties/2017-ava-evaluatie.pdf.

- Hay, D.C., Knechel, W.R., \& Wong, N. (2006). Audit fees: a meta-analysis of the effect of supply and demand attributes. Contemporary Accounting Research, 23(1): 141-191.

- Köhler, A.G., Marten, K.U., Ratzinger-Sakel, N., \& Wagner, M. (2010). Prüfungshonorare in Deutschland: Determinanten und Implikationen. Zeitschrift für Betriebswirtschaft, 80(1): 5-29.

- Köhler, A.G., \& Ratzinger-Sakel, N. (2012), Audit and non-audit fees in Germany, the impact of audit market characteristics. Schmalenbach Business Review, 64: 281-307.

- Langendijk, H. (2011). De toelichting omtrent het accountantshonorarium in de jaarrekening. Maandblad voor Accountancy en Be- driffseconomie, 85: 37-51.

- Langendijk, H., \& Speiicken, J. (2010). Een onderzoek naar de kwaliteit van de toelichting van het accountantshonorarium in de jaarrekening van grote Nederlandse bv's en nv's. In A.B. Hoogenboom, M. Pheilffer \& L. Paape (redactie), Accountancy in beweging (pp. 101119). Den Haag: Boom Juridische Ulitgeverii.

- NIVRA en NOvAA (2002). Nadere voorschriften inzake onafhankelijkheid van de accountant, Amsterdam en Den Haag: NIVRA en NOVAA.

- NIVRA (2009). Vermelding accountantshonorarium in de jaarrekening. NIVRA-Wijzer 1 , Amsterdam: NIVRA.

- RJ Raad voor de Jaarverslaggeving) (2013). RJ-Uiting 2013-16. Vermelding accountantshonoraria. Amsterdam: RJ. Geraadpleegd op https://www.rinet.n//Documents/litingen\%20 2013/RJ-Liting\%202013-16\%20Vermelding\%20Accountantshonoraria.pdf.

\section{Bijlage 1 Volledige tekst artikel 2:382a BW}

\footnotetext{
1. Opgegeven worden de in het boekjaar ten laste van de rechtspersoon gebrachte totale honoraria voor het onderzoek van de jaarrekening, totale honoraria voor andere controleopdrachten, totale honoraria voor adviesdiensten op fiscaal terrein en totale honoraria voor andere nietcontrolediensten, uitgevoerd door de externe accountant en de accountantsorganisatie, genoemd in artikel 1, eerste lid, onder a en e, van de Wet toezicht accountantsorganisaties.

2. Indien de rechtspersoon dochtermaatschappijen heeft of de financiële gegevens van andere maatschappijen consolideert, worden de honoraria die in het boekjaar te hunnen laste zijn gebracht, in de opgave begrepen.

3. De honoraria hoeven niet opgegeven te worden door een rechtspersoon waarvan de financiële gegevens zijn geconsolideerd in een geconsolideerde jaarrekening waarop krachtens het toepasselijke recht de verordening van het Europees Parlement en de Raad betreffende de toepassing van internationale standaarden voor jaarrekeningen of richtlijn 2013/34/EU van het Europees Parlement en de Raad van 26 juni 2013 betreffende de jaarlijkse financiële overzichten, geconsolideerde financiële overzichten en aanverwante verslagen van bepaalde ondernemingsvormen, tot wijziging van richtlijn 2006/43/EG van het Europees Parlement en de Raad en tot intrekking van richtlijnen 78/660/EEG en 83/349/EEG van de Raad (PbEU 2013, L 182) van toepassing is, mits de in lid 1 bedoelde honoraria in de toelichting van die geconsolideerde jaarrekening worden vermeld.
} 


\section{BIJLAGE 2 ONDERZOEKSPOPULATIE}

\begin{tabular}{|c|c|c|c|}
\hline Genoteerd op de & Onderneming & Genoteerd op de & Onderneming \\
\hline AEX & Aalberts & AMX & IMCD \\
\hline AEX & ABN AMRO & AMX & Intertrust \\
\hline AEX & AEGON & AMX & $\mathrm{OCl}$ \\
\hline AEX & Ahold Delhaize & AMX & Philips Lighting \\
\hline AEX & Akzo Nobel & AMX & PostNL \\
\hline AEX & Altice & AMX & Refresco Gerber \\
\hline AEX & Arcelor Mittal & AMX & Sligro \\
\hline AEX & ASM & AMX & TKH Group \\
\hline AEX & Boskalis & AMX & TomTom \\
\hline AEX & DSM & AMX & VastNed \\
\hline AEX & Galapagos & AMX & WDP \\
\hline AEX & Gemalto & AMX & Wereldhave \\
\hline AEX & Heineken & AScX & Accell \\
\hline AEX & ING & AScX & AMG \\
\hline AEX & KPN & AScX & Amsterdam Commodities \\
\hline AEX & NN Group & AScX & Basic-Fit \\
\hline AEX & Philips & AScX & Beter Bed \\
\hline AEX & Randstad & AScX & Binckbank \\
\hline AEX & RELX Group & AScX & Brunel \\
\hline AEX & SBN Offshore & AScX & Fagron \\
\hline AEX & Shell & AScX & ForFarmers \\
\hline AEX & Unibail-Rodamco & AScX & Heijmans \\
\hline AEX & Unilever & AScX & ICT Automatisering \\
\hline AEX & Vopak & AScX & Kas Bank \\
\hline AEX & Wolters Kluwer & AScX & Kendrion \\
\hline AMX & Air France-KLM & AScX & Kiadis Pharma \\
\hline AMX & Aperam & $A S c X$ & Lucas Bols \\
\hline AMX & Arcadis & AScX & Nedap \\
\hline AMX & ASMI & AScX & Nieuwe Steen \\
\hline AMX & ASR Nederland & AScX & Ordina \\
\hline AMX & BAM & $A S c X$ & Probiodrug \\
\hline AMX & Besi & $A S c X$ & Sif Holding \\
\hline AMX & Corbion & $A S c X$ & Stern Groep \\
\hline AMX & Delta Lloyd Groep & $A S c X$ & Takeaway.com \\
\hline AMX & Eurocomm Prop & $A S C X$ & Telegraaf Media Groep \\
\hline AMX & Flow Traders & AScX & Van Lanschot \\
\hline AMX & Fugro & AScX & Wessanen \\
\hline AMX & Grandvision & & \\
\hline
\end{tabular}




\section{BIJLAGE 3 UITSPLITSING AEX, AMX EN ASCX ACCOUNTANTSHONORARIA IN EUR '000}

\begin{tabular}{|c|c|c|c|c|c|c|c|c|c|c|c|}
\hline \multirow[t]{2}{*}{ AEX $(n=22)$} & & \multicolumn{2}{|c|}{2016} & \multicolumn{2}{|c|}{2015} & \multicolumn{2}{|c|}{2014} & \multicolumn{2}{|c|}{2013} & \multicolumn{2}{|c|}{2012} \\
\hline & & Bedrag & $\%$ & Bedrag & $\%$ & Bedrag & $\%$ & Bedrag & $\%$ & Bedrag & $\%$ \\
\hline \multirow{3}{*}{ Onderzoek van de jaarrekening } & Gemiddelde & 9.083 & 90 & 8.836 & 88 & 9.417 & 85 & 8.547 & 80 & 8.884 & 78 \\
\hline & Maximum & 46.550 & & 47.430 & & 41.500 & & 33.580 & & 34.960 & \\
\hline & Minimum & 515 & & 280 & & 121 & & 200 & & 200 & \\
\hline \multirow{3}{*}{ Andere controleopdrachten } & Gemiddelde & 647 & 6 & 723 & 7 & 764 & 7 & 1.094 & 10 & 1.452 & 13 \\
\hline & Maximum & 3.000 & & 2.300 & & 3.900 & & 4.500 & & 8.000 & \\
\hline & Minimum & - & & - & & - & & 10 & & - & \\
\hline \multirow{3}{*}{ Adviesdiensten op fiscaal terrein } & Gemiddelde & 74 & 1 & 274 & 3 & 706 & 6 & 776 & 7 & 746 & 6 \\
\hline & Maximum & 472 & & 1.224 & & 4.400 & & 3.200 & & 4.000 & \\
\hline & Minimum & - & & - & & - & & - & & - & \\
\hline \multirow{3}{*}{ Andere niet-controlediensten } & Gemiddelde & 246 & 3 & 195 & 2 & 160 & 2 & 293 & 3 & 359 & 3 \\
\hline & Maximum & 2.600 & & 2.700 & & 1.000 & & 1.400 & & 2.214 & \\
\hline & Minimum & - & & - & & - & & - & & - & \\
\hline Totaal & & 10.050 & 100 & 10.028 & 100 & 11.047 & 100 & 10.710 & 100 & 11.441 & 100 \\
\hline \multirow[t]{2}{*}{ AMX $(n=20)$} & & \multicolumn{2}{|c|}{2016} & \multicolumn{2}{|c|}{2015} & \multicolumn{2}{|c|}{2014} & \multicolumn{2}{|c|}{2013} & \multicolumn{2}{|c|}{2012} \\
\hline & & Bedrag & $\%$ & Bedrag & $\%$ & Bedrag & $\%$ & Bedrag & $\%$ & Bedrag & $\%$ \\
\hline \multirow{3}{*}{ Onderzoek van de jaarrekening } & Gemiddelde & 1.819 & 89 & 1.680 & 85 & 1.594 & 83 & 1.674 & 77 & 1.749 & 79 \\
\hline & Maximum & 5.900 & & 7.000 & & 7.500 & & 7.400 & & 7.600 & \\
\hline & Minimum & 118 & & 115 & & 103 & & 99 & & 98 & \\
\hline \multirow{3}{*}{ Andere controleopdrachten } & Gemiddelde & 133 & 6 & 236 & 12 & 192 & 10 & 240 & 11 & 208 & 9 \\
\hline & Maximum & 900 & & 911 & & 809 & & 842 & & 1.100 & \\
\hline & Minimum & - & & - & & - & & - & & - & \\
\hline \multirow{3}{*}{ Adviesdiensten op fiscaal terrein } & Gemiddelde & 72 & 4 & 46 & 2 & 94 & 5 & 186 & 8 & 158 & 7 \\
\hline & Maximum & 902 & & 372 & & 800 & & 1.600 & & 700 & \\
\hline & Minimum & - & & - & & - & & - & & - & \\
\hline \multirow{3}{*}{ Andere niet-controlediensten } & Gemiddelde & 25 & 1 & 20 & 1 & 37 & 2 & 87 & 4 & 112 & 5 \\
\hline & Maximum & 191 & & 211 & & 421 & & 700 & & 519 & \\
\hline & Minimum & - & & - & & - & & - & & - & \\
\hline Totaal & & 2.049 & 100 & 1.982 & 100 & 1.917 & 100 & 2.187 & 100 & 2.227 & 100 \\
\hline & & & & & & & & & & & \\
\hline
\end{tabular}




\begin{tabular}{|c|c|c|c|c|c|c|c|c|c|c|c|}
\hline \multirow[t]{2}{*}{$\operatorname{AScX}(n=20)$} & & \multicolumn{2}{|c|}{2016} & \multicolumn{2}{|c|}{2015} & \multicolumn{2}{|c|}{2014} & \multicolumn{2}{|c|}{2013} & \multicolumn{2}{|c|}{2012} \\
\hline & & Bedrag & $\%$ & Bedrag & $\%$ & Bedrag & $\%$ & Bedrag & $\%$ & Bedrag & $\%$ \\
\hline \multirow{3}{*}{ Onderzoek van de jaarrekening } & Gemiddelde & 599 & 80 & 561 & 80 & 517 & 78 & 491 & 74 & 553 & 68 \\
\hline & Maximum & 1.857 & & 1.410 & & 1.516 & & 1.851 & & 1.851 & \\
\hline & Minimum & 115 & & 125 & & 80 & & 80 & & 85 & \\
\hline \multirow{3}{*}{ Andere controleopdrachten } & Gemiddelde & 106 & 14 & 83 & 12 & 72 & 11 & 78 & 12 & 86 & 11 \\
\hline & Maximum & 879 & & 381 & & 400 & & 400 & & 600 & \\
\hline & Minimum & - & & - & & - & & - & & - & \\
\hline \multirow{3}{*}{ Adviesdiensten op fiscaal terrein } & Gemiddelde & 19 & 2 & 14 & 2 & 28 & 4 & 49 & 7 & 49 & 6 \\
\hline & Maximum & 168 & & 130 & & 232 & & 231 & & 242 & \\
\hline & Minimum & - & & - & & - & & - & & - & \\
\hline \multirow{3}{*}{ Andere niet-controlediensten } & Gemiddelde & 27 & 4 & 39 & 6 & 44 & 7 & 49 & 7 & 120 & 15 \\
\hline & Maximum & 444 & & 374 & & 572 & & 368 & & 1.155 & \\
\hline & Minimum & - & & - & & - & & - & & - & \\
\hline Totaal & & 751 & 100 & 697 & 100 & 661 & 100 & 667 & 100 & 808 & 100 \\
\hline
\end{tabular}

